\title{
The accumulation of potentially-toxic metals by grazing ruminants
}

\author{
J. M. Wilkinson ${ }^{1 *}$, J. Hill² and C. J. C. Phillips ${ }^{3}$ \\ ${ }^{1}$ School of Biology, University of Leeds, Leeds LS2 9JT, UK \\ ${ }^{2}$ Faculty of Applied Science and Technology, Writtle College, Writtle, Chelmsford, Essex CM1 3RR, UK \\ ${ }^{3}$ Department of Clinical Veterinary Medicine, University of Cambridge, Cambridge CB3 OES, UK
}

\begin{abstract}
The main factors affecting the accumulation of potentially-toxic metals (PTM) by grazing animals are the presence of the metal, its concentration in herbage and at the soil surface, and the duration of exposure to the contaminated pasture and soil. In addition, the elapsed time between the contamination of the pasture and grazing, the quantity of soil ingested together with herbage, the mechanism of absorption of the metal into blood and the presence or absence of antagonistic metals can interact to influence the rate and extent of accumulation of heavy metals in edible body tissues. Models of the accumulation of metals by grazing animals may be used to determine the statutory limits of radionuclides and PTM in soils under grazed pastures. Meta-analysis of existing data, using a random-effects model, is a useful approach to understanding the factors affecting the accumulation of some metals, e.g. Cd. The target edible body tissues for the accumulation of most PTM are the liver and kidneys, with the exception of radiocaesium, which accumulates in muscle to a greater extent than in other tissues. The livers and kidneys of mature livestock that have been grazed on areas of pasture at the legal limit of contamination by $\mathrm{Cd}$ for more than one grazing season should be removed from the human food chain in order to reduce the risk of intake of Cd by the human population.
\end{abstract}

Potentially-toxic metals: Grazing livestock: Contaminated pasture and soil: Accumulation in edible body tissues

The contamination of pastures and the accumulation of potentially-toxic metals (PTM) in grazing animals can occur on soils that are naturally rich in metals (for example, see Martin \& Coughtrey, 1982), following accidental or anthropogenic events such as the fall-out of radiocaesium on grassland after the accident at the Chernobyl nuclear reactor (Howard \& Beresford, 1994), or following the prolonged use of sewage sludge as a fertiliser (Wilkinson et al. 2001).

The definition of a 'heavy metal' is not clear. In many texts, metals with a density $>4$ or $5 \mathrm{~g} / \mathrm{l}$ are considered as being heavy metals. However, this definition would include the lanthanides and actinides that, chemically, have distinct properties. The classification preferred by many researchers is that of Nieboer \& Richardson (1980), in which elements with a density $>5 \mathrm{~g} / \mathrm{l}$ are grouped into three classes: A; B; borderline. Class A elements have a preference for ligands containing O (e.g. Mn, density $7.42 \mathrm{~g} / \mathrm{l}$ ). Class B elements show a preference to form ligands with $\mathrm{N}$ or $\mathrm{S}$ (e.g. Cd, density $8.65 \mathrm{~g} / \mathrm{l})$. Borderline elements are of intermediate nature between classes A and B (Table 1).
The chemical classification of 'heavy metals' into the three classes is important biologically. The characteristic of Class B elements to form ligands with $\mathrm{N}$ and/or S, includes metallothioneins (MT; Cousins, 1985; Lee et al. 1994), phytochelatin (Marschner, 1995), complexes with globular proteins (caeruloplasmin; Underwood \& Suttle, 1999) and excretion in bile (e.g. Cd; Kiyozumi \& Kojima, 1978). In grazing mammals the elements $\mathrm{Cd}$ and $\mathrm{Pb}$ tend to accumulate in the liver and kidneys, and in some cases (e.g. $\mathrm{Pb}$ ) also in bone (Lee et al. 1999). Many elements interfere with essential enzyme reactions and/or organ function (see p. 273); hence their potential toxicity to the grazing animal and man. Of particular concern is $\mathrm{Cd}$, because of the relatively low threshold of toxicity on the part of the animal to the presence of relatively low concentrations of this element in the body. The European Commission and national governments have recognised the potential toxicity of $\mathrm{Cd}$ and have set maximum limits for $\mathrm{Cd}$ in foods (Commission of the European Communities, 2001). The Commission of the European Communities (2002) has

\footnotetext{
Abbreviations: MT, metallothionein; OM, organic matter; PTM, potentially-toxic metals.

*Corresponding author: Dr J. M. Wilkinson, present address Painshall, Church Lane, Welton, Lincoln LN2 3LT, UK, fax +44 1673 863108, email mike@chalcombe.co.uk
} 
Table 1. Classification of selected essential and non-essential metal ions into classes A and B and borderline (based on Nieboer \& Richardson, 1980)*

\begin{tabular}{lcc}
\hline Class A & Borderline & Class B \\
\hline $\mathrm{Cs}$ & $\mathrm{Zn}$ & $\mathrm{Cd}$ \\
$\mathrm{Mn}$ & $\mathrm{Pb}$ & $\mathrm{Cu}$ \\
$\mathrm{Sr}$ & $\mathrm{Fe}$ & $\mathrm{Hg}$ \\
& $\mathrm{Cr}$ & $\mathrm{Ag}$ \\
& $\mathrm{Co}$ & \\
& $\mathrm{Ni}$ & \\
& $\mathrm{As}$ & \\
& $\mathrm{Sn}$ & \\
$\mathrm{V}$ &
\end{tabular}

${ }^{\star}$ For more detailed explanation, see Martin \& Coughtrey (1982)

recently reviewed heavy metals in wastes and their potential risk to the human food chain.

The present review is principally concerned with the different possible routes of entry of PTM into the body of the grazing animal. Although radiocaesium is not a toxic metal, as defined in Table 1, it is included because of its importance in the human food chain.

\section{Contamination of grassland by potentially-toxic metals}

Sources of PTM in soils have been reviewed extensively (for example, see Martin \& Coughtrey, 1982; Alloway, 1995). The distribution of metals is not uniform through the soil profile, because of progressive weathering and disintegration of rocks, the incorporation of organic matter (OM) by biological processes and the deposition of regolith by aerial and fluvial processes. Leaching, erosion, biological and microbial processes modify the localisation of metals within the soil.

The lateral and horizontal mixing of the surface soil, especially during cultivation, are major processes by which the localisation of heavy metals within the top $0.25 \mathrm{~m}$ of the soil may be altered. Metals in cultivated soils are generally more homogenously distributed in the top $0.25 \mathrm{~m}$ than in undisturbed soils. The concentration of metals in the top $0.075 \mathrm{~m}$ of the soil is of particular relevance because the roots of most grasses are in this region, and it is the surface soil that may be ingested along with herbage by the grazing ruminant (see p. 270). Contaminants may be deposited on the soil surface via aerial deposition (e.g. radionuclides, vehicle and industrial emissions), during flooding and by direct application to the ground (e.g. metals in fertilisers and in sewage sludge). The grazing animal can ingest the metals either by consuming herbage that is internally or externally contaminated (Aitken, 1997), or by consuming contaminated soil (see p. 271).

\section{Natural contamination of grassland}

In the UK there is considerable regional variation in PTM concentrations (McGrath \& Loveland, 1992), with particularly high concentrations in soils derived from marine black shales in south west and north west England and the West Midlands. These 'teart' soils can contain high Mo
Table 2. Typical concentrations of potentially-toxic metals $(\mathrm{mg} / \mathrm{kg})$ in soils derived from various parent materials (Curtis et al. 1976)

\begin{tabular}{lrrrr}
\hline & Serpentine & Granite & Shale & Sandstone \\
\hline $\mathrm{Co}$ & 80 & 2 & 20 & 3 \\
$\mathrm{Cr}$ & 3000 & 5 & 200 & 30 \\
$\mathrm{Cu}$ & 20 & 10 & 10 & 10 \\
$\mathrm{Mn}$ & 3000 & 700 & 1000 & 200 \\
\hline
\end{tabular}

concentrations, which reduce $\mathrm{Cu}$ availability in grazing stock. In carboniferous limestone areas where $\mathrm{Pb}$ is often mined, there are often fluvial-deposited sediments downstream, containing up to $6000 \mathrm{mg} \mathrm{Pb} / \mathrm{kg}$ (Alloway, 1999). Soils derived from igneous rocks can contain high concentrations of PTM (Table 2). Leaching of metals from such soils may be variable, and the subsequent deposition of the leached minerals in sedimentary rock may lead to the accumulation of metals to potentially-toxic levels (Curtis et al. 1976).

The main factors affecting toxic metal uptake by plants are the chemical speciation of the mineral fraction of the soil, the soil OM content, and soil permeability and chemical properties (Alloway, 1999). The mineralogy of the soil (especially the clay mineral fraction and the cation-exchange capacity) affects the pattern of release and retention of cations in the soil, even though Hill et al. $(1998 a, b)$ did not find cation-exchange capacity to affect accumulation of PTM in lambs. Adsorption of PTM to ligands, e.g. iron, manganese and aluminium oxides, is $\mathrm{pH}$ dependent and conferred by the ability of the PTM to form hydroxy complexes, typically in the order $\mathrm{Cd}>\mathrm{Ni}>\mathrm{Co}>\mathrm{Zn}>>\mathrm{Cu}$ $>\mathrm{Pb}>\mathrm{Hg}$. Complex formation with $\mathrm{OM}$ is typically $\mathrm{Pb}>\mathrm{Cu}$ $>\mathrm{Fe}=\mathrm{Al}>\mathrm{Mn}=\mathrm{Co}>\mathrm{Zn}$ (Alloway, 1999).

Soil chemical properties and soil permeability are closely related. The migration of air into the soil and leaching of soil water alter the oxidation-reduction conditions and soil solution $\mathrm{pH}$. The balance of oxidation-reduction conditions can alter the PTM speciation, and under anoxic conditions microbial methylation of $\mathrm{As}, \mathrm{Hg}, \mathrm{Sb}, \mathrm{Se}$ and $\mathrm{Tl}$ can convert these elements to more bioavailable and toxic forms (Lamy et al. 1993; Alloway, 1999). The combined effects of oxidation-reduction and change in soil $\mathrm{pH}$ on oxides of certain metals can lead to re-release or immobilisation of elements in the soil solution.

Soils derived from geological series of high metal concentration are the most likely to produce contaminated herbage. Thus, undisturbed soil profiles in metal-rich areas close to historical mining activity show elevated concentrations of metals in the uppermost part of the soil profile (Martin \& Coughtrey, 1982; McGrath \& Loveland, 1992), and are the most likely natural soils to be associated with supra-normal concentrations in plant tissues. Although the concentration of metals in plants generally reflects that in the soil, only in the case of $\mathrm{Cd}, \mathrm{Zn}, \mathrm{Ag}, \mathrm{Hg}$, Sn and Th does the range of metal concentration in plants reach equivalence with the median of that in the soil (Bowen, 1979). The range of concentrations of metals in plants is highly variable, reflecting, among other factors, the availability of the element, the presence or absence of competing ions and the composition and age of the plant community. 


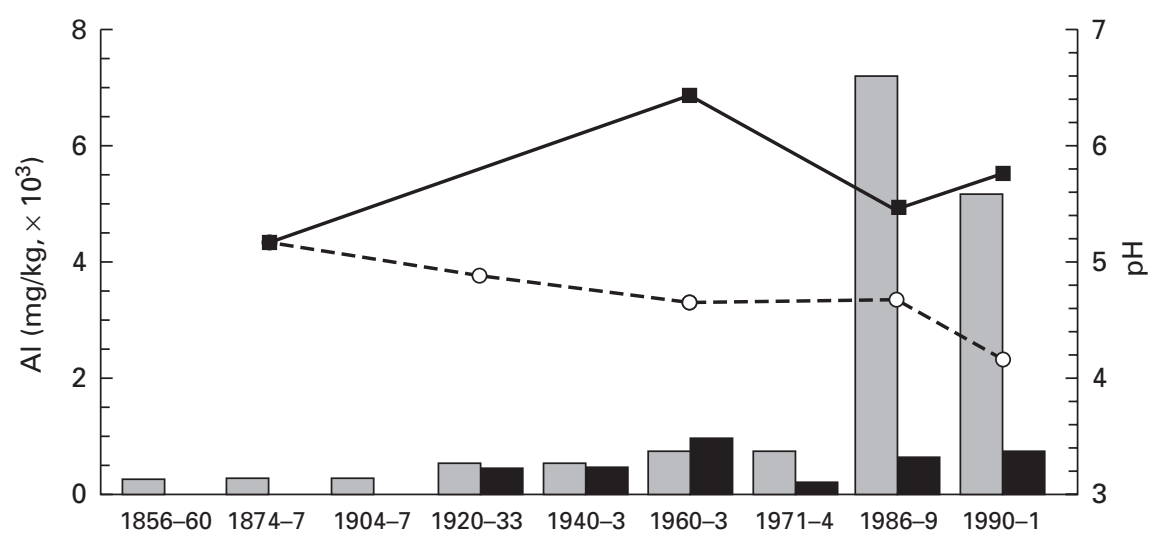

Fig. 1. Aluminium in hay from the Park Grass Experiment at Rothamsted, Herts. ( $\square$ ), Aluminium in hay, unlimed; $(\boldsymbol{\square})$, aluminium in hay, limed; $(\bigcirc---\bigcirc, \mathrm{pH}$, unlimed; $(\boldsymbol{\square}-\mathbf{\square}), \mathrm{pH}$, limed. (From Blake et al. 1994.)

Soil acidification, historically the result of the depletion of the soil cation exchange capacity by rainfall, and more recently by the direct deposition of $\mathrm{H}_{2} \mathrm{SO}_{4}, \mathrm{HNO}_{2}$ and $\mathrm{HNO}_{3}$ in rain following industrial activity, increases the availability of metals to the plant (Alloway, 1995). Thus, the UK statutory limits to the concentrations of $\mathrm{Zn}, \mathrm{Cu}$ and $\mathrm{Ni}$ in soils under grass increase with soil $\mathrm{pH}$ (Statutory Instrument, 1989). Without the intermittent remediation of soil $\mathrm{pH}$ by the addition of lime, it is likely that the concentrations of PTM in herbage will increase, especially if the plant community is growing slowly. An example of progressive soil acidification enhancing metal availability is when reduction of soil $\mathrm{pH}$ to 4.5 at Rothamsted, Herts., UK (Fig. 1) caused the concentration of $\mathrm{Al}$ in hay to exceed the maximum tolerable limit for animal feed (National Research Council, 1980).

\section{Accidental contamination of grassland}

There are many examples of accidental contamination of grassland, e.g. by radionuclides, mine wastewater containing $\mathrm{Cd}, \mathrm{Zn}, \mathrm{Cu}, \mathrm{Pb}$ and $\mathrm{As}$, shotgun pellets $(\mathrm{Pb}, \mathrm{Sb}$, $\mathrm{As}$ and $\mathrm{Ni}$ ), $\mathrm{Zn}$ and $\mathrm{Cu}$ in pylon 'drip', $\mathrm{Cd}$ in phosphatic fertilisers and a variety of metals in sewage sludge. However, few of the examples are linked directly to events leading to either toxicity of grazing livestock or to a reduction in animal performance (Commission of the European Communities, 2002).

Radiocaesium. Approximately $1.9-5 \times 10^{8} \mathrm{~Bq}$, comprising about thirty radionuclides, were released into the atmosphere from an explosion at the Chernobyl nuclear station in 1986. The most consequential radionuclides, from the point of view of the long-term contamination of land, were ${ }^{137} \mathrm{Cs}$ and ${ }^{90} \mathrm{Sr}$, with half-lives (d) of $1.1 \times 10^{4}$ and $1.02 \times 10^{4}$ respectively (Savchenko, 1995). The migration of ${ }^{137} \mathrm{Cs}$, ${ }^{134} \mathrm{Cs}$ and ${ }^{131} \mathrm{I}$ and their subsequent widespread deposition on land were the main causes of an increase in radioactivity in most European countries at this time (International Atomic Energy Authority, 1990).

Cs adsorbs strongly to clay particles in soil and consequently moves slowly through the soil profile, but it is also relatively unavailable to plants. In contrast, ${ }^{90} \mathrm{Sr}$ binds weakly to soil and is readily available to plants (Winteringham, 1989; Savchenko, 1995). However, the soils of many of the upland areas of the UK affected by the fallout of radionuclides were of low $\mathrm{pH}$ and low in clay concentration and, therefore, did not immobilise Cs (Livens et al. 1991). The concentrations of ${ }^{134+137} \mathrm{Cs}$ in the vegetation of north and north west areas of the UK 6 months after the Chernobyl accident were highly variable, probably reflecting the uneven pattern of rainfall after the accident rather than differences in soil type, and differences in herbage yield (for review, see Howard \& Beresford, 1994).

Contaminated natural fertilizers. Phosphatic fertilisers contain $\leq 280 \mathrm{mg} \mathrm{Cd} / \mathrm{kg} \mathrm{P}_{2} \mathrm{O}_{5}$ (Sumner \& McLaughlan, 1996), leading to accidental contamination of surface layers of soil (Williams \& David, 1973; Bramley, 1991) and accumulation in plant tissue (Lee et al. 1993). Phosphatic rocks of igneous origin usually contain less $\mathrm{Cd}$ than those of sedimentary origin $\left(<5 \mathrm{mg} \mathrm{Cd} / \mathrm{kg} \mathrm{P}_{2} \mathrm{O}_{5}\right)$, but comprise only approximately $0 \cdot 14$ of world phosphate resources (Environmental Resources Management, 1999; Aldinger, 2002). Several EU member states have set limits to the concentration of $\mathrm{Cd}$ in fertilisers (Environmental Resources Management, 2001), and proposals to have a progressive reduction in the maximum concentration, ultimately to $20 \mathrm{mg} \mathrm{Cd} / \mathrm{kg} \mathrm{P}_{2} \mathrm{O}_{5}$ by 2016 (Environmental Resources Management, 2001) are under consideration. Removal of $\mathrm{Cd}$ from rock phosphate is possible by co-crystallisation of $\mathrm{H}_{3} \mathrm{PO}_{4}$ with $\mathrm{CaSO}_{4}$ (gypsum) or, less attractively, by calcination with $\mathrm{CaCl}_{2}$ at $700-1100^{\circ}$ (Environmental Resources Management, 2001).

\section{Anthropogenic contamination of grassland}

Mining. Disturbed soils and spoil heaps from historical mining activity present a particular hazard to the grazing animal, since the concentrations of metals may be high in both topsoil and herbage. For example, Johnson \& Eaton (1980) noted that the concentrations $\mathrm{Cd}, \mathrm{Zn}$ and $\mathrm{Pb}$ were respectively three, two and five times higher in topsoil than in the subsoil around a derelict $\mathrm{Pb}-\mathrm{Zn}$ mine. $\mathrm{Pb}$ is one of the most common causes of poisoning in farm animals (Livesey, 1994); some poisoning is a result of grazing 
spoil heaps (Clegg, 1978). However, many incidents of $\mathrm{Pb}$ poisoning are the result of accidental exposure to point sources of $\mathrm{Pb}$ contamination of animal feed rather than chronic exposure (Livesey, 1994).

Smelters and brickworks. The uptake of $\mathrm{Pb}$ by plants is low (Wilson \& Cline, 1966), but in areas where aerial deposition of $\mathrm{Pb}$ on to grassland has occurred, for example close to $\mathrm{Pb}$ smelters or roads (see p. 270), the $\mathrm{Pb}$ concentration on herbage may be elevated, especially in winter (Dorn et al. 1975). Martin \& Coughtrey (1982), using data from Burkitt et al. (1972), reported increased $\mathrm{Pb}, \mathrm{Cd}$ and $\mathrm{Zn}$ on perennial ryegrass (Lolium perenne) up to $10 \mathrm{~km}$ from a $\mathrm{Pb}-\mathrm{Zn}$ smelter.

Sewage sludge (biosolids). The application of sewage sludge to grassland can result in elevated concentrations of PTM in the upper horizons of the soil (Davis et al. 1988). OM usually has a high cation-exchange capacity and strong absorptive capacity for PTM, which can be immobilised in soils rich in OM. However, the processes of OM degradation or chemical modification, for example when sewage sludge $\mathrm{OM}$ is added to soil, can alter the availability (Wilkinson et al. 2001, 2003).

Linear increases in $\mathrm{Cd}$ and $\mathrm{Cu}$ concentration in herbage, but not $\mathrm{Pb}$, have been observed with increasing soil concentrations in a review by Stark et al. (1998). Under field-scale conditions Wilkinson et al. (2001) observed elevated concentrations of $\mathrm{Cd}, \mathrm{Cu}$ and $\mathrm{Pb}$ in samples of unwashed herbage taken from grassland that had received repeated applications of sewage sludge over a 15-year period. The increase was greatest in the latter part of the grazing season. Some of the increases in PTM following application of sewage sludge were acknowledged to be derived from surface contamination.

Road traffic. Cars emit colloidal $\mathrm{Pb}$ and uncombusted $\mathrm{Pb}$ particulates containing tetra-alkyl lead, motor oil, $\mathrm{Cd}$ from tyres and $\mathrm{Zn}, \mathrm{Cu}, \mathrm{Mn}, \mathrm{Cr}$ and other metals from wear of moving metallic parts in the car. The tetra-alkyl lead compounds (anti-knocking agents) are more toxic than $\mathrm{Pb}$ salts as they penetrate through epidermal cells in animals (Merian, 1991). Roadside $\mathrm{Pb}$ concentrations in soil and herbage are expected to decline following the removal of $\mathrm{Pb}$ anti-knock agents from petroleum in most of Europe by 2005, according to the Aarhus agreement (Anon, 1998). However, $\mathrm{Pb}$ in soil has a half-life of several decades, depending on the OM content (Fowler et al. 1995). Once deposited on the soil, the $\mathrm{Pb}$ is rapidly complexed with organic compounds and resides in the upper strata that contain the greatest OM content (Branford et al. 1998). Emissions of $\mathrm{Pb}$ worldwide have caused progressive increases in soil $\mathrm{Pb}$ concentrations, at least until the removal of $\mathrm{Pb}$ from petrol (Jones et al. 1991; Renberg et al. 2000). In many developing countries $\mathrm{Pb}$ continues to be used in fuel, which can result in $\mathrm{Pb}$ concentrations of $80-7000 \mathrm{mg} / \mathrm{kg}$ herbage DM on busy roads (Motto et al. 1970). Animals grazing near roads where vehicles are using leaded petrol develop increased $\mathrm{Pb}$ concentrations in their blood, due to uptake from both pasture and soil (Ward et al. 1978). Soil intakes as high as $400 \mathrm{~g} / \mathrm{d}$ for grazing ewes (Healy, 1967) and $1.5 \mathrm{~kg} / \mathrm{d}$ for cattle (Dewes, 1986) have been reported.

$\mathrm{Pb}$ has been found in the milk of cows grazing roadside areas (Pittia, 1992), in mule deer forage in the Rocky
Mountain National Park (Harrison \& Dyer, 1984) and in hay and straw samples collected from roadsides (Swarup, 1993). Ward \& Savage (1994) found substantial quantities of $\mathrm{Pb}$ in the blood, wool and hair samples from sheep and horses grazing near the London orbital motorway. Although $\mathrm{Pb}$ has a relatively short half-life in blood (about 4 weeks) regular consumption ensures elevated concentrations in grazing animals. However, $\mathrm{Pb}$ does not spread more than a few metres from a vehicular emission source, even in the direction of the prevailing wind, so the animals have to be very close to the road to become contaminated. Systems of grazing cattle, sheep and horses close to roadways are still common in developing countries, where $\mathrm{Pb}$ is often still added to petrol. Such animals are often tethered, reducing their opportunity to select unpolluted herbage.

The metal abrasion in vehicles during motion also releases $\mathrm{Cd}$ and $\mathrm{Zn}$ onto neighbouring pastureland, but not in sufficient concentrations to pose a risk to grazing animals. These metals are also considerably more mobile in soil than $\mathrm{Pb}$. A form of emission of increasing importance is the low levels of $\mathrm{Pt}$ and $\mathrm{Pd}(<1 \mathrm{mg} / \mathrm{kg}$ fresh weight in soil and plants) derived from the catalytic after-burners of vehicular emissions (Hodge \& Stallard, 1986).

\section{Ingestion of potentially-toxic metals by the grazing animal}

The localisation of PTM in plants is dependent on the ability of the plant to either exclude the metal at the root-soil interface, particularly in the presence of vesicular arbuscular mycorrhizae, or to prevent the movement of the metal within the plant. Exclusion at the root-shoot interface is generally related to the production by the plant of lowmolecular-weight root exudates. These exudates are composed of sugars, amino acids, phenolic compounds and organic acids (Wiren et al. 1993). Typically, Mn, Fe and Al are sequestrated within concretions around roots derived from an interaction with low-molecular-weight root exudates (Marschner, 1995). Mobilisation of PTM can also occur as a result of formation of complexes of $\mathrm{Cd}$ and $\mathrm{Cu}$. These processes can have an effect on the uptake and movement of PTM in the root and shoot of the plant (Mench et al. 1988; Mench \& Martin, 1991).

The presence of phytochelatins to detoxify certain metals in plants is important in plant physiological terms, but may not be an efficient mechanism for excluding PTM from uptake by the grazing ruminant. Even if the PTM is bound in a phytochelatin, the fate of the metal (which is present in the form of a glutamylcysteine compound in the rumen and small intestine) is not known, but it is likely that the complex is degraded rapidly by the rumen microbial population, thus releasing the bound PTM.

$\mathrm{Cd}$ and $\mathrm{Zn}$ disperse to most root and shoot tissues, but can be confined to the meristem. $\mathrm{Pb}$ is generally localised in the root, if it has been taken up, and $\mathrm{Ni}$ tends to be distributed throughout the plant (Marschner, 1995).

The mechanisms of adhesion of PTM to herbage are poorly understood (Chaney \& Lloyd, 1979; Jones et al. 1979; Klessa \& Desira-Buttegieg, 1992; Aitken, 1997, 1998). $\mathrm{Cu}, \mathrm{Zn}$ and $\mathrm{Fe}$ are generally retained on herbage for periods greater than the UK statutory $21 \mathrm{~d}$ no-grazing period 
after the application of sewage sludge (Statutory Instrument, 1989), even under periods of high rainfall (Aitken, 1997), but the fate of $\mathrm{Cd}, \mathrm{Ni}$ and $\mathrm{Pb}$ is uncertain. The variability in retention of $\mathrm{Pb}$ is high $(\leq 85 \%)$ dependent on herbage factors as well as the type and association of $\mathrm{Pb}$ in the sludge. The variability may be partially explained by the extent of $\mathrm{PbS}_{2}$ formation and methylation of $\mathrm{Pb}$ in sludge digestion. Recontamination of the sward by rain splash and soil contamination of herbage is difficult to quantify (Beresford \& Howard, 1991), but could affect the amount of sludge-derived solids adhered to the herbage.

\section{Accumulation by the grazing animal of potentially-toxic metals in body tissues}

\section{Factors affecting uptake of elements by the animal}

Selective grazing behaviour. Cattle can detect lead acetate on pasture when it is present at concentrations of $\geq 45 \mathrm{mg}$ $\mathrm{Pb} / \mathrm{kg}$ DM (Strojan \& Phillips, 2002). They avoid lead acetate if exposed to it for a long period, especially at high concentrations, probably due to feedback of adverse effects on digestion (Strojan \& Phillips, 2002). However, cattle readily investigate novel objects in fields and can suffer acute toxicity following investigation of discarded $\mathrm{Pb}$ containing batteries, pipes and other objects. If they only have access to herbage contaminated with $\mathrm{Pb}$ the intensity of their grazing declines, as they reduce the time that they spend grazing each day and their rate of biting the pasture. The latter may be an indication of greater selectivity during grazing, which is also suggested by the slower rate of walking of cattle while they graze $\mathrm{Pb}$-contaminated pasture (Strojan \& Phillips, 2002). However, exposure to $\mathrm{Pb}$ contaminated pasture ameliorates the effects of $\mathrm{Pb}$ on cattle grazing behaviour, suggesting that either they learn to be more selective, or that they tolerate the contamination. The latter situation could occur with a gradual modification of rumen microflora so that $\mathrm{Pb}$ absorption decreases. However, there was no evidence of modification or an increase in herbage digestibility in sheep exposed to $\mathrm{Pb}$-contaminated feed for 1, 4 or 7 weeks (Mohamed, 2002). A possible reason for the reduction in $\mathrm{Pb}$ aversion with experience is that cattle become accustomed to the taste. However, it is more plausible that the aversion originates from adverse effects of digestion. Cattle showed no obvious aversion to the taste of $\mathrm{Pb}$ on herbage when it was first presented to them in different concentrations (Strojan \& Phillips, 2002). Taste aversions are more likely to develop for substances that have threatened the survival of grazing animals over a prolonged period.

Antagonistic elements. Antagonism may arise from direct competition for absorption sites in both the plant and animal, or from competition within the organism. Different mechanisms are responsible at different concentrations. For example, at low dietary concentrations $\mathrm{Cd}$ can directly compete with $\mathrm{Cu}$ for absorption sites, whereas at high concentrations the MT induction by $\mathrm{Cd}$ can bind $\mathrm{Cu}$ and render it unabsorbable (Gawthorne, 1987). A reduction in the $\mathrm{Cu}$ status of sheep has been observed with supplementary dietary Cd by Mills \& Dalgarno (1972).
Cd absorption is most commonly affected by the $\mathrm{Zn}$ status of animals, and Cd has been demonstrated to increase $\mathrm{Zn}$ accumulation in sheep, perhaps by the stimulation of MT production (Doyle \& Pfander, 1975; Grace et al. 1993; Lee et al. 1994). Conversely, Chiy et al. (1998) found that a high $\mathrm{Zn}$ intake reduces $\mathrm{Cd}$ absorption in sheep, suggesting competition between the two elements. Other researchers have found that $\mathrm{Cd}$ absorption in rats is independent of $\mathrm{Zn}$ status (Foulkes \& Voner, 1981). A simple competitive mechanism is unlikely, partly because the absorption of $\mathrm{Zn}$, but not Cd, is dependent on body status (Foulkes, 1984). The transport of Cd from the mucosa to the bloodstream is much less (approximately $1 \%$ ) than that of essential metals such as Zn, where it may reach $50 \%$ (Foulkes, 1984). $\mathrm{Cd}$ absorbed into mucosal cells, but not transferred to the bloodstream, is bound to cell membranes (Taguchi \& Suzuki, 1978) and returns to the gastrointestinal tract following the desquamation of these cells. By contrast, $\mathrm{Zn}$ is retained and may be released as required, depending on the body burden (Richards \& Cousins, 1975).

There is a negative effect of $\mathrm{Cd}$ in the small intestine on absorption of Fe, even at levels in the diet as low as $2.5 \mathrm{mg}$ $\mathrm{Cd} / \mathrm{kg} \mathrm{DM}$ (for example, see Bremner, 1978). At high concentrations MT induce necrosis of the proximal intestinal absorptive cells, which affects uptake of minerals, such as $\mathrm{Fe}$, for which the distal intestine cannot compensate (Valberg et al. 1977; Elsenhans et al. 1999). Pb is also commonly linked to Fe-deficiency-induced anaemia, although it is only rarely bound to MT. A reduction in haematopoiesis and inhibition of haem synthesis, with a decrease in $\delta$-aminolevulinic acid dehydrogenase, the enzyme that regulates haemoglobin production, has been observed in laboratory rodents. $\mathrm{Pb}$ poisoning of grazing mammals is most commonly acute following ingestion of $\mathrm{Pb}$ from discarded batteries, munitions or contaminated soil around areas where $\mathrm{Pb}$ was mined. It is not known whether livestock suffer anaemia following chronic $\mathrm{Pb}$ ingestion, such as near roadways.

As well as $\mathrm{Fe}, \mathrm{Pb}$ directly interacts with $\mathrm{Ca}, \mathrm{P}, \mathrm{Cu}, \mathrm{Mn}$ and $\mathrm{Zn}$, all of which protect against $\mathrm{Pb}$ absorption. There are also likely to be further direct and secondary interactions, which are currently not well understood.

The similarities between metals in their absorption characteristics have been examined as a dendogram (Fig. 2) for sheep given supplements of Cd and Zn (Chiy et al. 1998). Many of the elemental similarities can be predicted from the close correspondence in their atomic construction, e.g. $\mathrm{Na}$ and $\mathrm{K}$, but other similarities derive from their competition for the anions, in particular sulphate.

\section{Mechanisms of absorption}

A range of potential sites for absorption of metals exist from the rumen to the small intestine, but in grazing ruminants all metals are subject to the overriding influences of the rumen microbial digestion. The extent of absorption is also dependent on the species of metal ingested, the age of the animal (young animals generally absorb a greater proportion of ingested metal than old animals; Kello \& Kostial, 1977), other components of the feed (for review, see Rambeck, 


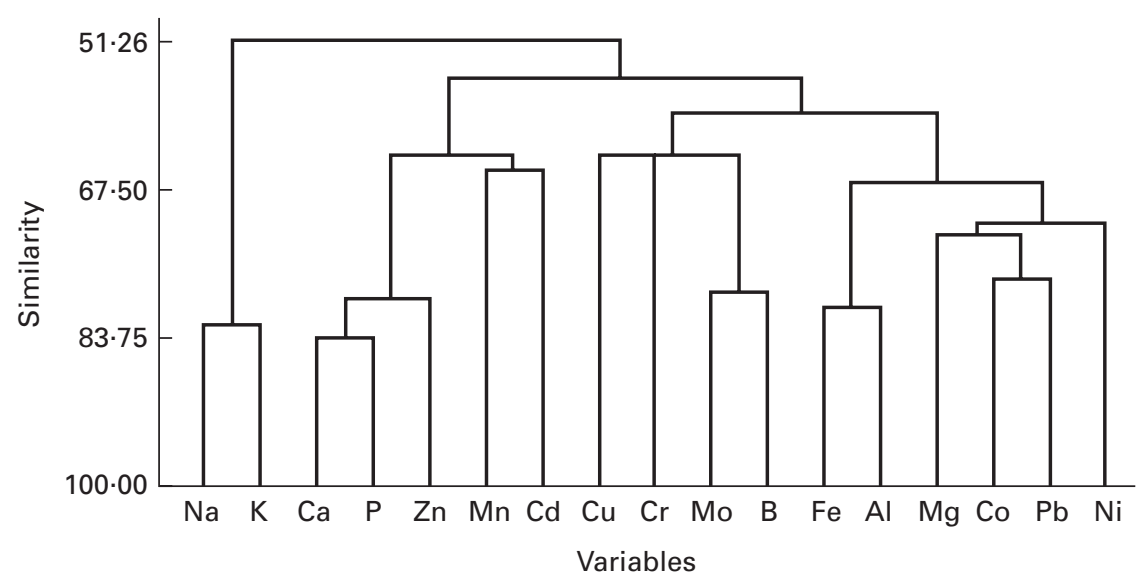

Fig. 2. Dendogram showing the similarity of elements in the mineral balance in sheep given supplements of cadmium and zinc. (From Chiy et al. 1998.)

1994), the $\mathrm{pH}$ of the medium (low $\mathrm{pH}$ dissociates ingested compounds) and the rate of passage through the gastrointestinal tract. Of these influences, age probably has the greatest effect, with young calves absorbing $\leq 50 \%$ of ingested $\mathrm{Pb}$, compared with $\leq 5 \%$ by older cattle. Most metals are ingested in an organic form, typically bound to phytochelatins, which are absorbed to a greater extent than metals ingested in an inorganic form (Zachou et al. 1997). Chelating agents such as ascorbic acid readily form complexes with toxic metals, such as $\mathrm{Cd}, \mathrm{Cu}$ and $\mathrm{Hg}$, and protect against toxicity of these metals. An adequate protein status has the same effect on the absorption of Cd.

Ionophores, e.g. monensin, form lipid-soluble complexes with many metals, including $\mathrm{Zn}$, which assists in their passage across membranes (Starnes et al. 1984; Snitsarev et al. 2001). They are often added to the diet of intensivelyfed ruminants, but are only rarely offered to grazing animals.

Metal accumulation will only occur if homeostatic or homeorhetic mechanisms cannot maintain a constant body composition. The absorption of many essential metals is controlled by these mechanisms, e.g. Zn whose absorption can vary from $<10 \%$ to $>80 \%$ depending on the animal's status (Underwood \& Suttle, 1999), but there is no reason why the mechanisms should have evolved for non-essential metals that were until recently rarely encountered in a sizeable quantity. Often these metals are characterised by low absorption rates, but they may utilise absorption mechanisms devised for other metals, e.g. $\mathrm{Cd}$ and $\mathrm{Zn}, \mathrm{Pb}$ and $\mathrm{Ca}$.

$\mathrm{Cd}$ is ingested either as Cd-MT or Cd-phytochelatin and may be partially digested in the gastrointestinal tract. The absorption of $\mathrm{Cd}$ takes place mainly in the proximal small intestine (Pigman et al. 1997), where it can damage the microvilli. Cd is initially absorbed by the intestinal mucosal cells and most of that absorbed eventually returns to the gastrointestinal tract following desquamation of the lumen cells, the rate of passage to the intestinal blood supply being extremely slow (Foulkes, 1984). In an experiment by Valberg et al. (1977) $300 \mathrm{~g} \mathrm{Cd} / \mathrm{kg} \mathrm{Cd}$ intake was absorbed by the intestinal mucosa, but as little as $10 \mathrm{~g} / \mathrm{kg}$ entered the body. Values for $\mathrm{Cd}$ absorption cited in the scientific literature vary widely, from $30 \mathrm{~g} / \mathrm{kg}$ to $200 \mathrm{~g} / \mathrm{kg}$ (Doyle et al. 1974; Piscator, 1985; Fox, 1987), with a value of $50 \mathrm{~g} / \mathrm{kg}$ being most commonly cited.

The uptake of $\mathrm{Cd}$ and $\mathrm{Zn}$ from the intestine is assisted by MT, which are low-molecular-weight cysteine-rich compounds present in moderate quantities in sheep (Henry et al. 1994). They compete with larger ligands, such as serum albumin (Foulkes \& Voner, 1981) or those in fibre (Cherian, 1979), which render the metal unabsorbable, at least in single-stomached animals. Rumen bacteria can dissociate some large ligands, such as phytic acid that binds to $\mathrm{Zn}$ (Oberleas et al. 1966), and there is evidence for increased absorption of organically-bound $\mathrm{Zn}$ in ruminants (Spears, 1966). Dissociated Cd complexes with Mo and thiomolybdenates to form insoluble compounds (Smith \& White, 1997) and bacterial MT, both of which have low absorption characteristics (Groten et al. 1992). Organicallybound $\mathrm{Cd}$, chelated by the carboxyl and amino group of amino acids, is probably protected from rumen degradation in sheep (Lee et al. 1999). There is no clear evidence of increased absorption of other organically-bound heavy metals, e.g. Cu (Suttle, 1994), compared with inorganic forms, but in mice Turecki et al. (1998) found reduced absorption of $\mathrm{Cd}$ in yeast compared with $\mathrm{CdCl}$.

The transport of $\mathrm{Cd}$ into the intestinal mucosal cells probably follows first-order kinetics, but may be assisted by low-molecular-weight ligands, in particular MT, although their presence is not obligatory for transport to take place (Foulkes, 1984). Saturation of the unassisted transport is probably reached at $\mathrm{Cd}$ concentrations of $0 \cdot 01-1 \mathrm{mM}$ (Koo et al. 1978; Foulkes, 1984). Many experiments have relied on measuring the $\mathrm{Cd}$ in target organs, principally the kidney, to estimate body retention. Estimates of the $\mathrm{Cd}-\mathrm{MT}$ absorbed by the kidney vary from $41 \%$ (Cain \& Griffiths, 1980) to $95 \%$ (Nordberg \& Nordberg, 1975). The binding of Cd by MT exacerbates the toxic effects on the intestinal mucosal cells, particularly by disturbing mitochondrial function (Valberg et al. 1977).

$\mathrm{Pb}$ absorption is also affected by the species and age of animals, with some disagreement on the proportion of intake that is absorbed. As little as $1 \%$ was reported to be absorbed by sheep (Blaxter, 1950), but other estimates in young calves 
are as high as $50 \%$. In short-term experiments absorption rates are often very high, as an extent of tissue saturation is reached, thereafter a steady-state is achieved, with much lower levels of retention following excretion in bile (Walker et al. 1996). As with many metals, proportionately more $\mathrm{Pb}$ is absorbed at high concentrations in feed as the sequestration of the $\mathrm{Pb}$ by chelating agents reaches saturation. There is no effective homeostatic protection against $\mathrm{Pb}$ absorption.

\section{Localisation of metal elements in the body}

Localisation is focused on the body's mineral storage and detoxifying organs, usually the liver for short- to mediumterm storage and detoxification, and the bones for long-term storage. The liver produces MT responsible for transporting $\mathrm{Zn}$ especially, but which will store considerable amounts of Cd.

$\mathrm{Cd}$ is present in the bloodstream as $\mathrm{Cd}-\mathrm{MT}$ and $\mathrm{Cd}-$ albumin in plasma and Cd-MT in erythrocytes. Cd bound to albumin is removed from the bloodstream by the liver and bound to MT produced by the hepatocytes. During natural apoptosis of these cells or liver damage the Cd-MT is released into the bloodstream. Having a low molecular weight, $\mathrm{Cd}-\mathrm{MT}$ is filtered by the kidney and re-absorbed in the proximal tubule. Here the complex is broken down by the lysosome system in the cells around the tubule lumen, and the Cd released will irreversibly damage tubular cells, causing interstitial fibrosis (Fowler, 1996), particularly when the detoxification system is overwhelmed. A similar condition has been described in human subjects (Fanconi syndrome; Marumo \& Li, 1996). Mitochondrial activity is substantially reduced and the endoplasmic reticulum and nucleus can be damaged. Adverse effects on kidney function can be measured by the excretion of B2microglobulin. $\mathrm{Cd}$ is excreted in the urine (Kjellstrom \& Nordberg, 1978), with a limited amount in bile and pancreatic juice (Prankel, 2002).

A meta-analysis of twenty-one experiments with sheep has recently been conducted which integrates previous findings in order to review existing legislation on permitted levels of $\mathrm{Cd}$ in animal feeds and organs (Prankel et al. 2001). Resulting predictions on Cd accumulation in sheep liver and kidneys are applicable to the broad set of exposure situations investigated in the individual studies. A randomeffects model, weighted for inter- and intra-trial variability, found that the two major predictors of $\mathrm{Cd}$ concentration in liver and kidney were the duration of exposure to $\mathrm{Cd}$ and the $\mathrm{Cd}$ concentration in the feed. The presentation of organically-bound $\mathrm{Cd}$, rather than inorganically-bound $\mathrm{Cd}$, also affected accumulation. Current maximum-permitted levels of feed $\mathrm{Cd}$ were entered into the model to show the extent to which the model predicts that tissues will exceed fitness for human consumption (under current EU and UK legislation). Most $\mathrm{Cd}$ consumed by sheep is in the organic form (bound to plant protein), so the values derived by experiments using inorganically-bound $\mathrm{Cd}$ are less relevant. The maximum period of time for which sheep could be offered feed containing the legally-permitted maximum concentration of $\mathrm{Cd}$ before their kidney and liver exceeded maximum-permitted Cd concentrations was 130 and $175 \mathrm{~d}$ respectively. A sheep's lifespan can easily exceed $130 \mathrm{~d}$ after weaning, and it is therefore not surprising that in national abattoir surveys sheep organs routinely exceed $\mathrm{Cd}$ limits. Potential measures to prevent increased risk to human health from dietary $\mathrm{Cd}$ of animal origin include prevention of the livers and kidneys of older sheep from contaminated regions entering the human food chain and strict implementation of current legislation. Reducing the animal's duration of exposure to high-Cd feed would be an expensive procedure. Lower limits on $\mathrm{Cd}$ concentration in sheep feed would enable the offal of older animals to be included, but would be difficult to impose as herbage that has been regularly fertilized with $\mathrm{P}$ or treated with sewage sludge already sometimes exceeds the legal limit. Routine removal of the liver and kidney of at least mature ewes from the human food chain is desirable in order to reduce human Cd intake.

In the laboratory rat the testis is one of the organs most affected by Cd, but Berry et al. (1999) were unable to show any adverse effects on semen quality of feeding rams $8 \mathrm{mg}$ $\mathrm{Cd} / \mathrm{d}$ for $60 \mathrm{~d}$. This level would be typical of sheep grazing a polluted site. $\mathrm{Cd}$ also accumulates in bones, where it has been responsible for severe osteopaenia and fractures in human subjects (itai-itai disease in Japan). The level of Cd present in muscle, milk or other edible body fractions is so low that usually it cannot be detected by spectroscopy.

$\mathrm{Pb}$ is absorbed in the small intestine and transported in the erythrocytes, where it replaces $\mathrm{Fe}$ in several enzymes concerned with haemoglobin production. $\mathrm{Pb}$ has a half-life of about $30 \mathrm{~d}$ in blood, so it may be used in the diagnosis of chronic and acute toxicity, with a threshold for acute exposure of about $0.4 \mu \mathrm{g} / \mathrm{l}$. High levels may be recorded long after acute exposure during periods of bone mobilisation, e.g. during early lactation.

$\mathrm{Pb}$ is also sequestered by the liver, but unlike $\mathrm{Cd}$ little is bound to MT, and most $\mathrm{Pb}$ is concentrated into storage sites, or intranuclear inclusion bodies (Goyer \& Wilson, 1975). It is ultimately stored in bones, particularly the long bones, although there are elevated concentrations in the kidney. The teeth and hair also contain elevated levels of $\mathrm{Pb}$.

Secretion of $\mathrm{Pb}$ into milk is rare unless an acute dose is ingested, since there is an exponential relationship between $\mathrm{Pb}$ intake and output in milk. $\mathrm{Pb}$ levels in milk increase rapidly at blood concentrations of $>0.2-0.3 \mathrm{mg} \mathrm{Pb} / \mathrm{kg}$ (Oskarsson et al. 1992). Despite the protection of bovine milk from $\mathrm{Pb}$ contamination, it has sometimes contained more $\mathrm{Pb}$ than human milk (0.04 v. 0.01 mg Pb/l; Pinkerton et al. 1973), Cattle are likely to release bone $\mathrm{Pb}$ into milk at, and soon after, parturition (Galey et al. 1990).

A major risk to the human food chain is the accumulation of ${ }^{137} \mathrm{Cs}$ in muscle tissue of ruminants grazing contaminated upland pastures (see pp. 269 and 270; Sansom, 1989; Beresford et al. 2000).

\section{Exposure and legal limits}

Exposure is a function of the concentration of PTM in herbage and the duration of consumption. These two factors are not necessarily additive. A long exposure to a small dose of $\mathrm{Cd}$, for example, would be unlikely to induce acute toxicity because of the ability of the liver to sequester $\mathrm{Cd}$ bound to MT. A short 'provocative' dose is likely to exceed the liver's 
ability to sequester the metal and acute toxicity arises when the metal passes through the proximal tubule of the kidney.

The critical dose of $\mathrm{Cd}$ that will produce chronic toxicity in sheep is approximately $2.5 \mathrm{mg} / \mathrm{kg}$ body weight per d, with a dose $>0.5 \mathrm{mg} / \mathrm{kg}$ body weight per $\mathrm{d}$ for 1 year likely to produce subclinical effects (Prankel, 2002). In the latter case it is recommended by Hapke \& Abel (1977) that the liver and kidney are discarded in order to reduce $\mathrm{Cd}$ intake by human subjects. Accumulation in muscle only occurs after much higher doses $(30 \mu \mathrm{g} \mathrm{Cd} / \mathrm{g}$ feed), which are unlikely to occur even in the most polluted regions (Hapke \& Abel, 1977).

The long half-life of $\mathrm{Pb}$ in the body, approximately onethird of the total lifespan, ensures that most absorbed $\mathrm{Pb}$ is accumulated rather than excreted. Maximum-permissible levels of $\mathrm{Pb}$ in soils have been established by the EU (Commission of the European Communities, 1991), and in some countries Codes of Good Practice reinforce measures to minimise contamination in soils (Ministry of Agriculture, Fisheries and Food, 1993). In animal feeds there is a legal limit set by the Feeding Stuffs Regulations in the UK for the $\mathrm{Pb}$ content of a complete diet feed $(5 \mathrm{mg} \mathrm{Pb} / \mathrm{kg})$, with $10 \mathrm{mg}$ $\mathrm{Pb} / \mathrm{kg}$ allowed in raw material foods (Statutory Instrument, 1995). However, grass, lucerne (Medicago sativa) and clover (Trifolium spp.) meal may contain $\leq 40 \mathrm{mg} \mathrm{Pb} / \mathrm{kg}$, and phosphates may contain $30 \mathrm{mg} \mathrm{Pb} / \mathrm{kg}$, emphasising that some limits are set on the grounds of practicality rather than on objective criteria. A dose of $6 \mathrm{mg} \mathrm{Pb} / \mathrm{kg}$ body weight per $\mathrm{d}$ fed for $60 \mathrm{~d}$ can be fatal to growing cattle (Hammond \& Aronson, 1964), but adult cattle can tolerate up to twice this dose (Buck, 1970). The maximum-permissible level in the feed of cattle or sheep in the USA is $30 \mathrm{mg} \mathrm{Pb} / \mathrm{kg}$ (National Research Council, 1980).

Many countries enforce limits of heavy metals in air, but these levels are mainly relevant to those working indoors in the metal industries, rather than animals (or human subjects) outside. Threshold limit values are defined for short (15 min) and long-term human exposure, and a limit that cannot be breached for any length of time. World Health Organization (1900) guidelines for Cd in air of 0.5-1 g/l are stricter than the Commission of the European Communities (2002) legal limit of $2 \mu \mathrm{g} / \mathrm{l}$.

Concentrations of radiocaesium in upland pastures have declined progressively in the 22 years since the Chernobyl accident, as radioactivity decayed and the element moved down the soil profile and out of the root layer of the vegetation. Thus, the number of sheep in the UK under restricted movement because their muscle tissue contains more than the intervention concentration of $1000 \mathrm{~Bq}$ ${ }^{137} \mathrm{Cs} / \mathrm{kg}$ fresh weight has decreased from $2 \times 10^{6}$ in 1986 to 200000 in 2002 (UK Department for the Environment, Food and Rural Affairs, personal communication).

Ploughing of grassland, preceded by the incorporation of zeolite, has been found to decrease the level of radioactivity in subsequent crops by five- to sevenfold (Savchenko, 1995). However, in some unploughable upland peat soils the decrease in the concentration of Cs in herbage has been relatively slow and movement restrictions persist (UK Department for the Environment, Food and Rural Affairs, personal communication). Sheep grazing these areas are monitored annually in May or June. If slaughter is desired, contaminated animals may be moved to uncontaminated lowland pastures. They are monitored again 3 months later and, if the concentration of ${ }^{137} \mathrm{Cs}$ in muscle tissue is below the current intervention limit, they may enter the food chain, subject to further monitoring at abattoirs.

Currently, in the UK the intervention concentration of ${ }^{137} \mathrm{Cs}$ in sheep muscle tissue is under review (UK Department for the Environment, Food and Rural Affairs, personal communication). The movement of sheep from affected areas to slaughter is no longer restricted in Northern Ireland (UK Department for the Environment, Food and Rural Affairs, personal communication).

\section{References}

Aitken MN (1997) Short term leaf surface adhesion of heavy metals following application of sewage sludge to grassland. Grass and Forage Science 52, 73-85.

Aitken MN (1998) Impact of applying agricultural and nonagricultural waste to farmland. Proceedings, Veterinary Public Health Association/British Veterinary Association Scientific Meeting 1998. pp. 1-15. London: British Veterinary Association.

Aldinger H (2002) The current debate on regulating the risk associated with cadmium in phosphate fertilizer in the European Union. Proceedings of the 8th International Conference of the Arab Fertilizer Association. Cairo: Arab Fertilizer Association.

Alloway BG (1995) Heavy Metals in Soils, 2nd ed. Glasgow: Blackie Academic and Professional.

Alloway BG (1999) Land contamination and reclamation. In Understanding our Environment, pp. 199-236 [RM Harrison, editor]. Cambridge: Royal Society of Chemistry.

Anon (1998) Lead Free. The Bulletin, vol. 8. Szentendre, Hungary: Regional Environmental Center of Central and Eastern Europe.

Beresford NA, Barnett CL \& Mayes RW (2000) Radiocaesium variability within sheep flocks: determination of 137Cs intake in free-ranging sheep. Radiation and Environmental Biophysics 39, 207-212.

Beresford NA \& Howard BJ (1991) The importance of soil adhered to vegetation as a source of radionuclides ingested by grazing animals. The Science of the Total Environment 107, 237-254.

Berry NR, Axford RFE, ap Dewi I, Chiy PC \& Phillips CJC (1999) The effect of a low dose of cadmium on spermatogenesis in rams. Small Ruminant Research 32, 97-102.

Blake L, Johnston AE \& Goulding KWT (1994) Mobilisation of aluminium in soil by acid deposition and its uptake by grass cut for hay - a Chemical Time Bomb. Soil Use and Management 10, $51-55$.

Blaxter KL (1950) Lead as a nutritional hazard to farm livestock. II. The absorption and excretion of lead by sheep and rabbits. Journal of Comparative Pathology and Therapeutics 60, 140-159.

Bowen HJM (1979) Environmental Chemistry of the Elements. London: Academic Press.

Bramley RGV (1991) Cadmium in New Zealand agriculture. New Zealand Journal of Agricultural Research 33, 505-519.

Branford D, Mourne RW \& Fowler D (1998) Spatial variations of wet deposition rates in an extended region of complex topography deduced from measurements of $\mathrm{Pb}-210$ soil inventories. Journal of Environmental Radioactivity 41, 111-125.

Bremner I (1978) Cadmium toxicity. In World Review of Nutrition and Dietetics. vol. 32, Human and Animal Nutrition, pp. 165-197 [GH Bourne, editor]. Basel: S.Karger. 
Buck WB (1970) Lead and organic pesticide poisoning in cattle. Journal of American Veterinary Medicine Association 156, $1468-1472$.

Burkitt A, Lester P \& Nickless G (1972) Distribution of heavy metals in the of an industrial complex. Nature, London 238, 327328.

Cain K \& Griffiths B (1980) Transfer of liver cadmium to the kidney after aflatoxin induced liver damage. Biochemical Pharmacology 29, 1852-1855.

Chaney RL \& Lloyd CA (1979) Adherence of spray-applied digested sewage sludge to tall fescue. Journal of Environmental Quality 8, 407-411.

Cherian MG (1979) Metabolism of orally-administered Cdmetallothionein in mice. Environmental Health Perspectives 28, 127-130.

Chiy PC, de la Fuente M, Barrado E, Vega M \& Phillips CJC (1998) The determination of mineral balances in sheep offered feed with added cadmium and zinc. Fresenius Journal of Analytical Chemistry 361, 343-348.

Clegg FG (1978) Lead pollution in Derbyshire due to mining and industry. State Veterinary Journal 33, 41-48.

Commission of the European Communities (1991) Directive (ECD) $199186 / 278 /$ EEC. Protection of the environment and in particular the soil, when sewage sludge is used in water. Official Journal of the European Commission L181, 6-12.

Commission of the European Communities (2001) Directive EC $466 / 2001$. Setting maximum levels for certain contaminants in foodstuffs. Official Journal of the European Commission L77, $1-13$.

Commission of the European Communities (2002) Heavy Metals in Waste. Brussels: Commission of the European Communities.

Curtis LF, Courtney FM \& Trudgill ST (1976) Soils in the British Isles. London: Longman.

Cousins RJ (1985) Absorption, transport and hepatic metabolism of $\mathrm{Cu}$ and $\mathrm{Zn}$ : Special reference to metallothionein and ceruloplasmin. Physiological Reviews 65, 238-309.

Davis RD, Carlton-Smith CH, Stark JH \& Campbell JA (1988) Distribution of metals in grassland soils following surface applications of sewage sludge. Environmental Pollution 49, 99-115.

Department of the Environment (1974) Lead in the Environment and its Significance to Man. London: H. M. Stationery Office.

Dewes HF (1986) The rate of soil ingestion by dairy cows and the effect on availabilities of $\mathrm{Cu}, \mathrm{Ca}, \mathrm{Na}$ and $\mathrm{Mg}$. New Zealand Veterinary Journal 44, 199-200.

Dorn CR, Pierce JO, Chase GR \& Phillips PE (1975) Environmental contamination by lead, cadmium, zinc and copper in a new lead producing area. Environmental Research 9, 159-172.

Doyle JJ \& Pfander WH (1975) Interactions of cadmium with copper, iron, zinc and manganese in ovine tissues. Journal of Nutrition 105, 599-606.

Doyle JJ, Pfander WH, Grebing SE \& Pierce JOD (1974) Effect of dietary cadmium on growth, cadmium absorption and cadmium tissue levels in growing lambs. Journal of Nutrition 104, 160-166.

Elsenhans BG, Hunder G, Strugala G \& Schumann K (1999) Longitudinal pattern of enzymatic and absorptive functions in the small intestine of rats after short-term exposure to dietary cadmium chloride. Archives of Environmental Contamination and Toxicology 36, 341-346.

Environmental Resources Management (1999) Study on Data Requirements and Programme for Data Production and Gathering to Support a Future Evaluation of the Risks to Health and the Environment from $\mathrm{Cd}$ in Fertilisers. Final Report to the European Commission - DGIII, March 1999. London: ERM.

Environmental Resources Management (2001) Analysis and Conclusions from Member States' Assessment of the Risk to Health and the Environment from $\mathrm{Cd}$ in Fertilisers. Final Report to the European Commission - DGIII, October 2001. London: ERM.

Foulkes EC (1984) Intestinal absorption of heavy metals. In Pharmacology of Intestinal Permeation, vol. 1, pp. 543-565 [TZ Csáky, editor]. Berlin: Springer Verlag.

Foulkes EC \& Voner C (1981) Effects of zinc status, bile and other endogenous factors on jejunal cadmium absorption. Toxicology 22, 115-122.

Fowler BA (1996) The nephropathology of metals. In Toxicology of Metals, pp. 721-729 [LW Chang editor]. Boca Raton, FL: CRC Publishers.

Fowler D, Mourne R \& Branford D (1995) The application of $\mathrm{Pb}-210$ inventories in soil to measure long-term average wet deposition of pollutants in complex terrain. Water, Air and Soil Pollution 85, 2113-2118.

Fox MR (1987) Assessment of cadmium, lead and vanadium status of large animals as related to the human food chain. Journal of Animal Science 65, 1744-1752.

Galey FD, Slenning BD, Anderson ML, Breneman PC, Littlefield ES, Melton L \& Tracey ML (1990) Lead concentration in blood and milk from periparturient dairy heifers seven months after an episode of acute lead toxicosis. Journal of Veterinary Diagnostic Investigation 2, 222-226.

Gawthorne JM (1987) Copper interactions. In Copper in Man and Animals, vol. 1, pp. 79-99 [JM Howell and JM Gawthorne, editors]. Boca Raton, FL: CRC Press Inc.

Goyer RA \& Wilson MH (1975) Lead-induced inclusion bodies. Results of ethylenediaminetetra-acetic acid treatment. Laboratory Investigation 32, 149.

Grace ND, Rounce JR \& Lee J (1993) Intake and excretion of cadmium in sheep fed fresh herbage. Proceedings of the New Zealand Society of Animal Production 53, 251-253.

Groten JP, Luten JB, Bruggeman IM, Temmink JHM \& Vanbladeren PJ (1992) Comparative toxicity and accumulation of cadmium chloride and cadmium metallothionein in primary cells and cell lines of rat intestine, liver and kidney. Toxicology Vitro 6, 509-517.

Hammond PB \& Aronson AL (1964) Lead poisoning in cattle and horses in the vicinity of a smelter. Annals of the New York Academy of Sciences 111, 595-611.

Hapke H-J \& Abel J (1977) Die Ansammlung von Cadmim in verzehrbaren Geweben in abhangigkeit von der Cd-Menge im Futter (The accumulation of cadmium in the food chain from cadmium in fodder). Archiv fur Lebensmittelhygiene 28, 174-177.

Harrison PD \& Dyer MI (1984) Lead in mule deer forage in Rocky Mountain National Park, Colorado. Journal of Wildlife Management 48, 510-517.

Healy WB (1967) Ingestion of soil by sheep. Proceedings of the New Zealand Society of Animal Production 27, 109-120.

Henry RB, Liu J, Choudhuri S \& Klassen CD (1994) Species variation in hepatic metallothionein. Toxicology Letters 74, 23-33.

Hill J, Stark BA, Wilkinson JM, Curran MK, Lean IJ, Hall JE \& Livesey CT (1998a) Accumulation of potentially toxic elements by sheep given diets containing soil and sewage sludge. 1. Effects of type of soil and level of sewage sludge in the diet. Animal Science 67, 73-86.

Hill J, Stark BA, Wilkinson JM, Curran MK, Lean IJ, Hall JE \& Livesey CT (1998b) Accumulation of potentially toxic elements by sheep given diets containing soil and sewage sludge. 2 . Effect of ingestion of soils treated historically with sewage sludge. Animal Science 67, 87-96.

Hodge VF \& Stallard MO (1986) Platinum and palladium in roadside dust. Environmental Science and Technology 20, 1058-1060.

Howard BJ \& Beresford NA (1994) Radiocaesium contamination of sheep in the United Kingdom after the Chernobyl accident. In Pollution in Livestock Production Systems, pp. 97-118 [I Ap 
Dewi, RFE Axford, I Fayez, M Aarai and HM Omed, editors]. Wallingford, Oxon.: CAB International.

International Atomic Energy Authority (1990) The Radiological Consequences in the USSR from the Chernobyl Accident: Assessment of Health and Environmental Effects and Evaluation of Protective Measures. Vienna: IAEA.

Johnson MS \& Eaton JW (1980) Environmental contamination through residual trace metal dispersal from a derelict lead-zinc mine. Journal of Environmental Quality 9, 175-179.

Jones KC, Symon C, Taylor PJL, Walsh J \& Johnston, AE (1991) Evidence for a decline in rural herbage lead levels in the UK. Atmospheric Environment 25A, 361-369.

Jones SG, Brow KW, Deuel LE \& Donnelly KC (1979) Influence of simulated rainfall on the retention of sludge heavy metals by the leaves of forage crops. Journal of Environmental Quality $\mathbf{8}$, 69-72.

Kello D \& Kostial K (1977) Influence of age on whole-body retention and distribution of $115 \mathrm{~m}$ cadmium in the rat. Environmental Research 14, 92-98.

Kiyozumi M \& Kojima S (1978) Studies on poisonous metals V. Excretion of cadmium through bile and gastro-intestinal mucosa and effect of chelating agents on its excretion in cadmiumpretreated rats. Chemical Pharmacology Bulletin, Tokyo 26, 3410-3415.

Kjellstrom T \& Nordberg GF (1978) A kinetic model of cadmium metabolism in the human being. Environmental Research 16, 248-269.

Klessa DA \& Desira-Buttegieg A (1992) The adhesion to leaf surfaces of heavy metals from sewage sludge applied to grassland. Soil Use and Management 8, 115-121.

Koo SI, Fullmer CS \& Wasserman RH (1978) Intestinal absorption and retention of $109 \mathrm{Cd}$; Effects of cholecalciferol, calcium status and other variables. Journal of Nutrition 108, 1812-1822.

Lamy I, Bourgeois S \& Bermond A (1993) Soil cadmium mobility as a consequence of sewage sludge disposal. Journal of Environmental Quality 22, 731-737.

Lee J, Grace ND, Mackay AD, Hedley MJ \& Rounce JR (1993) Cadmium in soil, pasture and grazing ruminants. Proceedings of the XVII International Grassland Congress, pp. 817-818. Palmerston North, New Zealand: Massey University.

Lee J, Masters DG, White CL, Grace ND \& Judson GJ (1999) Current issues in trace element nutrition of grazing livestock in Australia and New Zealand. Australian Journal of Agricultural Research 50, 1341-1364.

Lee J, Teloar BP \& Harris PM (1994) Metallotheonein and trace element metabolism in sheep tissues in response to high and sustained $\mathrm{Zn}$ dosages. I. Characterisation and turnover of metallothionein isoforms. Australian Journal of Agricultural Research 45, 303-320.

Livens FR, Horrill AD \& Singleton, DL (1991) Distribution of radionuclides in the soil-plant systems of upland areas. Health Physics 60, 539-545.

Livesey CT (1994) Contamination of animal feeds: A review of principal causes, detection, investigation and control of toxic contaminants. In Pollution in Livestock Production Systems, pp. 19-41 [I Ap Dewi, RFE Axford, I Fayez, M Aarai and HM Omed, editors]. Wallingford, Oxon.: CAB International.

McGrath SP \& Loveland PJ (1992) The Soil Geochemical Atlas of England and Wales. Glasgow: Blackie Academic and Professional.

Marschner H (1995) Mineral Nutrition of Plants. London: Academic Press.

Martin MH \& Coughtrey PJ (1982) Biological Monitoring of Heavy Metal Pollution. London: Applied Science Publishers.

Marumo F \& Li JP (1996) Renal disease and trace elements. Nippon Rinsho 54, 93-98.
Mench M \& Martin E (1991) Mobilisation of cadmium and other metals from two soils by plant root exudates of Zea mays L., Nicotiana tabacum L., and Nicotiana rustica L. Plant and Soil 132, 187-196.

Mench M, Morel JL, Guckert A \& Guillet B (1988) Metal binding with root exudates of low molecular weight. Journal of Soil Science 39, 521-527.

Merian E (1991) Speciation of metal compounds (interrelation between chemistry and biology). Trac-Trends in Analytical Chemistry 10, 172-175.

Mills CF \& Dalgarno AC (1972) Copper and zinc status of ewes and lambs receiving increased dietary concentrations of cadmium. Nature 239, 171-173.

Ministry of Agriculture, Fisheries and Food (1993) Code of Good Practice for the Protection of Soil. London: MAFF.

Mohamed MO (2002) Effect of supplementary nutritive and toxic elements on the mineral balances and preferences of ruminants. $\mathrm{PhD}$ Thesis, University of Cambridge.

Motto HL, Daines RH, Chilko DM \& Motto CK (1970) Lead in soils and plants: Its relationship to traffic volume and proximity to highways. Environmental Science and Technology 4, 231.

National Research Council (1980) Lead in the Human Environment. Washington, DC: National Academy of Sciences.

Nieboer E \& Richardson DHS (1980) The replacement of the nondescript term 'heavy metals' by a biologically and chemically significant classification of metal ions. Environmental Pollution 1B, 3-26.

Nordberg M \& Nordberg GF (1975) Distribution of metallothionein-bound cadmium and cadmium chloride in mice: preliminary studies. Environmental Health Perspectives 12, 103-108.

Oberleas D, Muhrer ME \& O'Dell BL (1966) Dietary metalcomplexing agents and zinc availability in the rat. Journal of Nutrition 90, 56-62.

Oskarsson A, Jorhim L, Sundberg J, Nilsson NG \& Albanus L (1992) Lead poisoning in cattle, transfer of lead to milk. Science of the Total Environment 111, 83-94.

Pigman EA, Blanchard J \& Laird HE (1997) A study of cadmium transport pathways using the Caco-2 cell model. Toxicology and Applied Pharmacology 142, 243-247.

Pinkerton C, Hammer DI, Birdbord K, Creason JP, Kent JL \& Murthy GK (1973) Human milk as a dietary source of cadmium and lead. In Trace Substances in Environmental Health - VI. A symposium, pp. 000-000 [DD Hemphill, editor]. Columbia, MO: University of Missouri.

Piscator M (1985) Dietary exposure to cadmium and health effects: impact of environmental changes. Environonmental Health Perspectives 63, 127-132.

Pittia P (1992) Indagine sul contenuto in piombo in latte della Provincia di Udine (The content of lead in milk from the Province of Udine). Scienza e Tecnica Lattiero Casearia 43, 201-208.

Prankel S (2002) Models of cadmium accumulation in sheep and cattle as a part of the human food chain. $\mathrm{PhD}$ thesis, University of Cambridge.

Prankel SH, Nixon RM \& Phillips CJC (2001) A meta-analysis of cadmium accumulation in sheep liver and kidney. Toxicology 164, Suppl., 73.

Rambeck WA (1994) Influences on the carry-over of cadmium in the food chain. Proceedings of the Society of Nutrition Physiology 2, 23-29.

Renberg I, Brannvall ML, Bindler R \& Emteryd O (2000) Atmospheric lead pollution history during four millennia (2000 BC to 2000 AD) in Sweden. Ambio 29, 150-156.

Richards MP \& Cousins RJ (1975) Mammalian zinc homeostasis; Requirement for RNA and metallothionein synthesis. 
Biochemical and Biophysical Research Communications 64, 1215-1223.

Sansom BF (1989) An assessment of the risks to the health of grazing animals from the radioactive contamination of pastures. British Veterinary Journal 145, 206-211.

Savchenko VK (1995) The Ecology of the Chernobyl Catastrophe. Paris: UNESCO.

Smith GM \& White CL (1997) A molybdenum-sulfur-cadmium interaction in sheep. Australian Journal of Agricultural Research 48, 147-154.

Snitsarev V, Budde T, Stricker TP, Cox JM, Krupa DJ, Geng L \& Kay AR (2001) Fluorescent detection of $\mathrm{Zn}(2+)$-rich vesicles with Zinquin: mechanism of action in lipid environments. Biophysical Journal 80, 1538-1546.

Spears JW (1966) Organic trace elements in ruminant nutrition. Animal Feed Science and Technology 58, 151-163.

Stark BA, Livesey CT, Smith SR, Wilkinson JM \& Cripps PJ (1998) Implications of Research on the Uptake of PTEs from Sewage Sludge by Grazing Animals. Report to the Department of the Environment, Transport and the Regions (DETR) and the Ministry of Agriculture, Fisheries and Food (MAFF). London: H. M. Stationery Office.

Starnes SR, Spears JW, Froetschel MA \& Croom WJ (1984) Influence of monensin and lasalocid on mineral metabolism and ruminal urease activity in steers. Journal of Nutrition 114, $518-525$.

Statutory Instrument (1989) The Sludge (Use in Agriculture) Regulations Statutory Instrument no. 1263. London: H. M. Stationery Office.

Statutory Instrument (1995) The Feeding Stuffs Regulations 1995. Statutory Instrument no. 1412. London: H. M. Stationery Office.

Strojan ST \& Phillips CJC (2002) The detection and avoidance of lead contaminated pasture by cattle. Journal of Dairy Science $\mathbf{8 5}$, 3045-3053.

Sumner ME \& McLaughlan MJ (1996) Contaminants and Soil Environment in the Australasia-Pacific Region. Dordrecht, The Netherlands: Kluwer Academic Publishers.

Suttle NF (1994) Meeting the copper requirements of ruminants. In Recent Advances in Animal Nutrition pp. 173-178 [PC Garnsworthy and DJA Cole, editors]. Nottingham: Nottingham University Press.

Swarup D (1993) Lead in feed and blood of bovines in varied environmental localities. Indian Journal of Veterinary Research 2, 34-37.
Taguchi T \& Suzuki S (1978) Cadmium binding components in the supernatant fraction of the small intestinal mucosa of rats administered cadmium. Japanese Journal of Hygiene 33, 467-473.

Turecki T, Cibulka J, Slamova A \& Barcalikova R (1998) Effect of organic and inorganic forms of dietary cadmium on cadmium, zinc, copper, iron and manganese availability to rats. Tierphysiologie Tierartz Futtermittung 78, 119-128.

Underwood EJ \& Suttle NF (1999) The Mineral Nutrition of Livestock, 3rd ed., pp. 514-517. Wallingford, Oxon.: CABI International.

Valberg LS, Haist J \& Cherian MG (1977) Cadmium-induced enteropathy: comparative toxicity of cadmium chloride and cadmium-thionein. Journal of Toxicology and Environmental Health 2, 963-975.

Walker CH, Hopkin SP, Sibly RM \& Peakall DB (1996) Principles of Ecotoxicology, pp. 67-103. London: Taylor and Francis Ltd.

Ward NI, Brooks RR \& Roberts E (1978) Blood lead levels in sheep exposed to automotive emissions. Bulletin of Environmental Contamination and Toxicology 20, 44-51.

Ward NI \& Savage MJ (1994) Elemental status of grazing animals located adjacent to the London Orbital (M25) motorway. Science of the Total Environment 147, 185-189.

Wilkinson JM, Hill J \& Livesey CT (2001) Accumulation of potentially toxic elements by sheep grazed on grassland given repeated applications of sewage sludge. Animal Science 72, 179-190.

Wilkinson JM, Hill J \& Hillman JP (2003) The accumulation of potentially toxic elements in edible body tissues of lambs after a single application of sewage sludge. Water Research 37, 128-138.

Williams CH \& David DJ (1973) The effects of superphosphate on the cadmium content of soils and plants. Australian Journal of Soil Science Research 11, 43-56.

Wilson DO \& Cline JF (1966) Removal of plutonium ${ }^{239}$, tungsten ${ }^{185}$ and lead ${ }^{210}$ from soils. Nature 209, 941-942.

Winteringham FPW (1989) Radioactive Fallout in Soils, Crops and Food. FAO Soils Bulletin no. 61, Rome: FAO.

Wiren N, von Rumheld V, Morel JL, Guckert A \& Marschner H (1993) Influence of microorganisms on iron acquisition in maize. Soil Biology and Biochemistry 25, 371-376.

Zachou E, Phillips CJC \& Chiy PC (1997) Relative effects of organic and inorganic sources of cadmium on nutrient bioavailability. In Bioavailability 97, Conference Proceedings, p. 135. Wageningen, The Netherlands: The VLAG Graduate School. 